\title{
Environmental Development in West Java
}

\author{
Candradewini $^{1}$, Budiman Rusli ${ }^{2}$ \\ ${ }^{1,2}$ University of Padjadjaran, Faculty of Social and Political Sciences, Jl. Raya Jatinangor, Bandung - Sumedang, Indonesia
}

\begin{abstract}
To sustain his life, humans have managed environment unilaterally, in the sense of its own to meet his needs a momentary nature has been exploiting natural resources, unwittingly this attitude has been lying to yourself in a sense sacrifice the future for the generations of the next generation. This is a problem in the implementation of the development if formulated explicitly concerned with environmental issues and the issue of residency which interplay with one another. In order to safeguard the sustainability of nature, the development of environmentally is an option, because it is a mix of matching, aligned and balanced between the systems ecologist, social systems and economic systems. The alignment is hoped the development will increase the quality of human life and to maintain environmental sustainability. In west java province some natural resources, which should merit attention to the development of environmentally sound is this : forest resources, water and the soil. Those resources has a great influence on the development of environmentally sound. They have a very close and inseparable because the interplay also deals causally.
\end{abstract}

Keywords: Development, environment, environmental, sustainability

\section{Introduction}

The development is in fact the human effort in order to improve the quality of life. To achieve this goal required a variety of resources that does little good, human resources as well as natural resources obtained from the environment. Associated with it, or not realized until recently mankind has manages environmental unilaterally, in the sense of its own to meet his needs a momentary nature has been exploiting natural resources, unwittingly this attitude has been lying to yourself in a sense sacrifice the future for the generations of the next generation. This is a problem in the implementation of the development if formulated explicitly concerned with environmental issues and the issue of residency which interplay with one another.

On this the Government of Indonesia to take them seriously, as evidenced by the issuance of several legal basis regulating the management of these environments. Starting with the Law of the Republic of Indonesia No. 4 of 1982 on "Provisions Principles of Environmental Management". Subsequently amended by Law No. 231997 About Environmental Management. In this law was formulated that the environment as a whole with all things space, power state, and living things, including humans and their behavior. Then followed up with Government Regulation No. 27 Year 2012 on Environmental Impact Assessment. In West Java, state and environmental problems have also become obstacles in local development activities. Salient issues and directly affect the sustainable development activities are: forest resources, soil, and water. All three are triumvirate that can not be separated. Forest area in West Java 1.02066 million ha which means from $23.1 \%$ of the area of West Java. Activity population is still difficult to prevent encroachment that forest destruction continues to grow and vice versa forest area was reduced. This directly results in the area of disturbed land for water catchment, and practical arrangements affect waterways and groundwater storage. It is a challenge for local governments, especially more for development planners in West Java.

\section{Literature}

\section{Environment}

The science of the environment developed based on a discipline called ecology .The term ecology is derived from the greek language, namely oikos which means the house , which means of science and logos .Literally ecology means the science of living things in his house or the science of households living beings (Soemarwoto, 1985). And the function of ecological studies the arrangement of all living creatures and other components of life, while the science of environmental studies the place and the role of human life among living creatures and other components .Thus the science of the environment is basically ecology applied to that talk about how to apply the principle and the ecology that in human life, or can be said that the science of the environment is the science that studies how mansuia have to put himself in his life in the environment or ecosystem .

In the science of environmental what was at stake not only the mutual relations and cause and effect between humans and its environment, but also whether the works of men provide benefits and risk against him; toward others and with other living creatures.If conferring benefits; means human actions are true and but if on the other hand means what he has done wrong. So the science of the environment contain a moral namely considerations of right or wrong.Hence the science of the environment must be moral to include natural inward moral humans ( suharto papers, 1994 ).

Environmental management is an effort to substantially increase the human qualities, and the quality of the environment remain live .So it looks here that talk about the environment could not take away from human problem or more precisely the problem of population .

\section{Development}

Through development activities well-being of the community can be upgraded to the direction of better, but unfortunately always faced with the risk of damage to the environment especially if the construction was not sustained or not environmentally sound.With the development could actually 


\section{International Journal of Science and Research (IJSR) \\ ISSN (Online): 2319-7064}

Index Copernicus Value (2013): 6.14 | Impact Factor (2014): 5.611

do business to raise the benefit of resources used by means of increasing the efficiency of the use of resources, for example a system of recycling. The importance of business increase the efficiency of that is :

1)For the source of power that can not be renewed, the increase in exploitation will accelerate shrinkage resources; while for resources that can be renewed, the increase in the intensity of exploitation will heightens the risk of natural devastation .

2)The use of resources a larger in general to enlarge also pollution problems .

In countries that are developing with a relatively large population adds to the complicated issues facing. The higher the number of the population, the higher the rate of resource requirements, particularly in terms of land it needs. The expansion of arable land lots going on-land marginal land, as steep hills and streams, as well as forestry land. Damagevisible damage to the environment are soil erosion, the erosion of the gene, and the increase in run-off that magnify the risk of flooding. Another problem that arises due to the pressure of a high rate of population growth is the migration from the villages to the cities to look for additional sources of revenue. In the city of any damage to the environment. Slums and wild, bad sanitation, unemployment and an increase in the number and quality of criminality. All this makes the construction is konditio sin quanon for developing countries.

\section{Environmentally sound development}

The orientation of the development of environmentally sound is meet the needs of human current with walk in observance of environmental sustainability to victuals of generation in the future.Thus in substance a goal for development that environmentally sound is :

1)Meet the needs of people now live without ignoring the needs and the ability of future generations .

2)Efforts to live from potential of natural, without damaging and just spend it .

3)The ability to manage natural resources natural resources ) , human resources and capital to improve long-term prosperity and well-being .

From a description of the purpose of the construction of environmentally (PBL) acquired a reflection that the construction of environmentally is the result of a combination of ecological systems, social systems and the economic system.

From a description of a goal for development environmentally sound ( pbl) it obtain an an illustration that the development of environmentally sound is the result of a combination of a system of ecology, the economic system and the system of social.

The purpose of a system of ecology is :

1) The improvement and maintenance of biodiversity

2)Productivity the management of ecosystems

3) The resilience utilization and the preservation of biodiversity

4) The development and equal distribution of rights belonging to natural resources.
The purpose of the economic system is :

1) The fulfillment of basic human needs

2) The increase in the utilization of natural resources that can be renewed

3)A decrease in productivity level of waste

4)Distribution of the responsibility of the development of environmentally sound

Whereas the purpose of a social system are :

1) The stabilisation of the population

2)An increase in quality of life

3)Increase community participation in the development of environmentally

For more details regarding the construction of environmentally sound can be seen that images as follows : Pictures : the construction of environmentally sound (PBL)

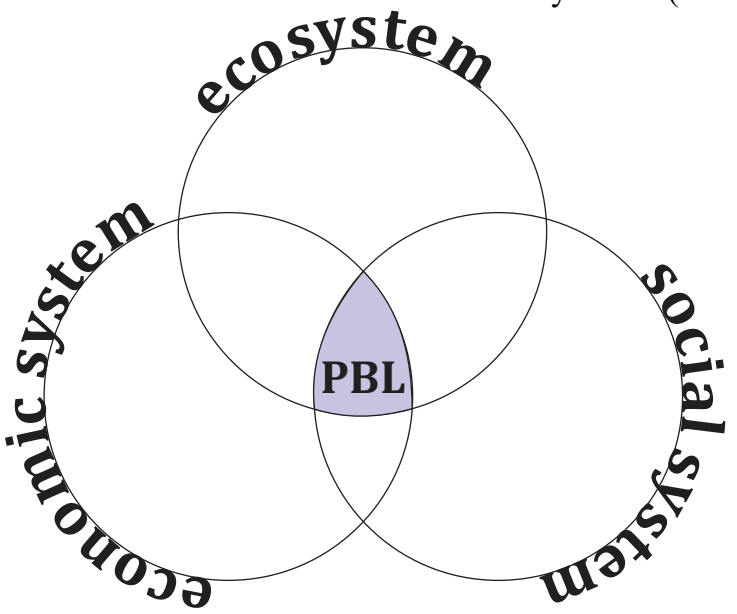

From the picture, it seems that the development environment (light blue part) is a blend of harmonious and balanced between ecologists systems, social systems and economic systems. This alignment with the expected result of development can improve the quality of human life while maintaining environmental sustainability.

\section{Discussion}

National development currently underway has the goal of achieving a fair and prosperous society equitable material and spiritual. For this purpose we adhere to two important principles, namely: First, the life of the balance, which is between the interests of the world and the hereafter, between the material and spiritual interests, the interests of the individual and society. Second, is the principle of fair and equitable namely that materiil and spiritual results achieved in development should be enjoyed equitably and meet eligibility for the values of human life adapted to a given value of devotion to the nation.

In implementing the national development is inseparable from the multitude of problems that must be faced and handled carefully which substantially relate to environmental issues and population who each other are inseparable.

The impact of population growth and socio-economic stresses that development is intended to improve the quality of the environment in both the micro and macro scale. 


\section{International Journal of Science and Research (IJSR) \\ ISSN (Online): 2319-7064}

Index Copernicus Value (2013): 6.14 | Impact Factor (2014): 5.611

Development impact can be positive for the macro scale, but have a negative impact on the micro scale or otherwise be positive for the micro scale, but negative in the macro scale development. Effort underway right now is how to keep the development of a positive impact both on the micro and macro scale, ie through environmentally sound development activities (PBL) applied in the entire territory of the country of Indonesia.

In west java some natural resources is a problem in the implementation of environmentally sound development. Of several natural resources that there are three natural resources will be discussed here given its influence very prominent and between the one having links with another closely so that just cannot be separated. Natural resources referred to as has been mentioned in the advance is forest resources, land and water .

\section{Forest}

According to the ministerial decree number 195 / Kpts-II / 2003 dated 4 July 2003 on the appointment of Forests and Water Areas of West Java Province forest area in West Java is 816603 ha, which means $21.9 \%$ of the total area of $3,727,681.44$ ha West Java , But according to data from FAO sources, the forest area of West Java is far from the expected, which is only about 0.5 million ha, or $10 \%$ of the area of West Java. Of the two different data sources is still difficult to ascertain which one is more accurate, in spite of the obvious it is with this minimum forest cover (less than a third of the total area) has consequences on decreasing function of soil protection from erosion. With the rainfall in West Java which is quite high, mountainous topography and land use that are less good, the attrition rate indicates the number of critical, for example Ciliwung River Basin over the past 62 years is the erosion increased more than 30 times (Suharto, 1994).

\section{Water}

As we know, the forest has the function of regulating the flow of water to be evenly distributed throughout the year by reducing water runoff (water loss) and raising the ground water deposits that can add to the flow in the dry season. With the damage and shrinking forest area in West Java, resulting in high water runoff. According to data from the Directorate General of Water Resources, Ministry of Public Works Year 1990/1991, Water runoff varied between $21.3 \%$ to $57.4 \%$, with an average rainfall of $43.1 \%$. The cause of this reduction in water flow can be caused by two things: first, because it seep into the ground that will come out again as springs, second, because evapotranspiration (evaporation). Except for surface water, ground water have also been utilized for domestic and industrial purposes, including the tourism industry. In Bandung has occurred groundwater has dropped from an average of $32.61 / \mathrm{sec}$. In 1982 to 18.11 / $\mathrm{sec}$ in 1988. Another result is a decrease in ground water level an average of 4.6 meters per year. In Tangerang to Bekasi has occurred subsidence and infiltration (intrusion) of sea water inland. Apart from the quantity of water continues to decrease, the quality is not good due to domestic and industrial waste. Water pollution by waste indsutri continues to show increasing numbers. One third of the total number of large and medium industries there and Greater Bandung area
(World Bank, 1990). High pollution are also in Situ Saguling sourced from industry and settlements along Citarum upstream Saguling, including Bandung, Cimahi, Majalaya and Banjaran. This fact is very alarming considering the need for water in West Java continues to increase, it is estimated that in 2020 , in the dry season water available will not be able to meet the primary needs.

\section{Land}

High rainfall in west java and a mountainous topographically causing danger erosion is quite high.It is more compounded again by the custom of the use of land inadequate and irrational.Compared with in central java and east java the potential danger erosion in west java higher.One example is ciliwung has any mud $1,150 \mathrm{mg} / 1$ in 1911 and 1912 and $36.500 \mathrm{mg} / \mathrm{l}$ in the year of 1974 the increase in more than 30 times as much in the last 60 years (world bank, 1990 ).

One of the difficulty of reduction in agricultural land erosion in west java is the dry soil layer over thickly so that farmers did not feel a decrease in the results by erosion

Various efforts have been made to protect its productive of erosion, one of them is by making natural heritage .In 1989 in west java there are 38 natural heritage with broad 182.233 ha , two genera asylum for of 13.528 ha , 17 tourist park area of 4.366 ha , and a garden birds of 12.120 ha .The total number of is 212.247 ha .Four natural heritage which is natural heritage the krakatau mount, natural heritage island panaitan peucang and an island, natural heritage of ujung kulon and natural heritage in mountain honje tanun 1980 set into a national park ujung kulon with 78.619 total wide of the ha .Three natural heritage another namely cibodas natural heritage , mountain gede , cimungkat natural heritage and natural heritage mountain gede-pangrango in 1980 designated as a national park mountain gede-pangrango with broad 15,000 ha .

For the establishment of natural heritage west java has experience and the role of a very important because historically making natural heritage expanded first in indonesia is in west java, namely natural heritage cibodas in 1885 with broad at that time 1,040 ha

\section{Some staple for environmentally sound development programs in west java}

Based on the discussion that has been presented, can be obtained a picture that the development of environmentally sound in west java face the challenges that is not lightly therefore based on the facts and the potentials should be taken by the wisdom of the regional government relating to the programs needed in order to implement environmentally sound development in west java .Programs that submitted this is advice based on thinking and analysis of simple so that should be tested further .Programs referred to is as follows :

1) Still need to be developed nature reserve expansion program with the aim of raising the water infiltration into the soil so as to reduce the danger of erosion.

2)Rehabilitation and forest reserves must be done consistently in addition to protecting the biological resources also keep forests function as a regulator of the traffic channel ground water.

\section{Volume 5 Issue 1 January 2016}




\section{International Journal of Science and Research (IJSR) \\ ISSN (Online): 2319-7064}

Index Copernicus Value (2013): 6.14 | Impact Factor (2014): 5.611

3)Need to be established specifically by the local government agency to oversee the use of groundwater, especially by industry, so its use does not exceed the capacity.

4) The awareness program is needed to arouse public awareness of the importance of savings and efficiency in the use of irrigation water.

5)Required a special team to control pollution caused by domestic waste (residential) and industry.

6)Program control of agricultural land to non-agricultural use needs attention, given the many city people with deep pockets want to turn it into a tourist spot, the inn and so unproductive

Some of the recommended program is expected to support the smooth construction of environmentally Middle implemented in West Java.

\section{Conclusion}

Given humans tend to feel that the resource was created for him and he is entitled to exploit as much as possible. So he felt life outside the ecosystem, regardless of the damage to the environment because it considered environmental damage will not affect him. This view is encouraging people to exploit the potential of nature to beyond the limit without thinking of the interests in the future. With the concept of environmentally sound development, such a view is to be changed. Natural potentials necessary for development but not by destroying it, especially over the natural resources that only disposable and can not be renewed as oil and gas. Therefore, sustainability and harmony be maintained. This is what needs attention in any development activities as well as in West Java.

In the province of west java, some natural resources that must be attention in order to implement the development of environmentally sound is: forest resources, water, and the land .Third resources it had a big influence on the success of the environmentally sound development. All three have relationship very closely and cannot be separated because in addition to affect each other also deals causally .

Although the results obtained not in accordance with the hope , but at least the development of environmentally sound this in terms of aspects of cognitive and affective evocative all parties about the importance of maintaining balance the ecosystem

\section{References}

[1] Bintoro T. 2000.Pengantar Administrasi Pembangunan.Jakarta :LP3ES.

[2] Budiman, Arif. 1993. Pembangunan di Indonesia Memandang dari Sisi lain. Jakarta : Yayasan Obor Indonesia berkerja sama dengan INFID.

[3] Korten, David C. 1993. Menuju Abad ke 21 Tindakan Sukarela dan Agenda Global. Jakarta : Yayasan Obor Indonesia.

[4] Pamudji. S.2004. Ekologi Administrasi Negara.Jakarta:Bumi Aksara.
[5] Rusli, Budiman.2014.Isu-Isu Krusial Administrasi Publik Kontemporer. Bandung : Lepsindo.

[6] Soerjani, Mohamad dkk. 1987. Lingkungan, Sumber Daya Alam dan Kependudukan Dalam Pembangunan. Jakarta : UI Press.

[7] Soemarwoto, Otto. 1985 Ekologi, Lingkungan dan Pembangunan. Jakarta : Djambatan.

[8] Suharto. 1994. Keserasian Penduduk dan Lingkungan Hidup. Bandung : Materi Pelatihan Demografi Pusat Penelitian Kependudukan Lembaga Penelitian UNPAD.

[9] Office of the Minister of State for Development Supervision and environmental Life : Law of the Republic of Indonesia No. 23 Year 1997 on Environmental Management.

[10] The ministerial decree number 195 / Kpts-II / 2003 dated 4 July 2003 on the appointment of Forests and Water Areas of West Java Province.

[11] Development Bureau for Population and Environment Setwilda of West Java: Indonesian Government Regulation No. 27 Year 2012 on Environmental Impact Assessment.

\section{Author Profile}

Candradewini, Candidate Ph.D in Public Administration, Lecturer at Faculty of Social and Political Sciences, University of Padjadjaran.

Budiman Rusli, Professor of Public Administration, Senior Lecturer at Faculty of Social and Political Sciences, University of Padjadjaran. 